Puss tried the door, and mewed, thinking, probably, some one must be near, and after waiting two or three minutes in vain, again sprang up the trellis, and renewed her attack on the bellwire, of course to be immediately admitted by the delighted maid, who this time did not cross the yard, nor ever again, I fear sometimes to the inconvenience of visitors, if puss was waiting for admission.

Now I think Mr. Henslow will concede that no one ever taught that cat how to ring the bell by pulling the wire. To my mind she must have gone through the following process of reasoning:- 1 . She noticed whenever the bell rang the door opened. 2. In elambering up the trellis to the house-top she accidentally moved the wire, and caused the bell to ring. This probably occurred several times before she noticed it, but having once done so, she repeated it, purposely, whenever she wanted entrance; I have often made her do it for the amusement of friends, by turning her out from her snug nest by the fire on cold or wet days.

I have known dogs shake a door violently to attract attention and be let in. A dear old spaniel of ours, at the Cape, used to rattle the empty bucket if he was thirsty, and then come and look in our faces. My horse will come up from his pasture to the pump in the yard and whinny till some one gives him water. I have known several dogs rear up and place their paws on the old-fashioned "thumb-latch," and let themselves in. Surely all this is "abstract reasoning"? These things are not taught them, and they do not do all of them, even by imitation, I don't go to the pump and whinny, if I want drink! nor rattle a bucket! No! they come by a process of mental reasoning, and I am convinced all animals have it to a certain degree, more or less. I could multiply instances by the page-full, but have already taken up too much space. Among others I could confirm the gnawing of water-pipes by rats to get at the water.
Brit. Consulate, Noumea, May 30
E. L. LAYARD

As a contribution to the doubtless numerous cases in which dogs have recognised the representations in paintings, I put on record the following fact :-

I have in my possession a small picture in which several degs are represented; a small spaniel was frequently found standing on a chair before the picture and barking at it, and this was the only picture of which he took any notice.

P. B. M.

\section{Black Lizards}

From the interesting letters of Messrs. Giglioli and Ernst it appears that lizards are found of a black colour where, according to received ideas, they ought to be nearly white. How is this anomaly to be explained?

With all due respect to those who have made this subject their study for tens of years, it seems to me that they keep too exclusively to one single proposition, which may be thus enunciated : An organism is made to prey or be preyed upon. What I am inclined to maintain is that an unfavourable climate is the common enemy of all, an enemy that must be eluded. If an animal be thrown into a climate too hot, or too cold, it will die if it cannot speedily adapt itself to its altered surroundings. We see a mild case of this adaptation to environment in man himself, the pale-face of temperate zones becoming soon in torrid zones bronzed, and, after a few generations, black. The black dermal covering is therefore clearly the one which is best adapted for extreme heat.

I submit then that here we have the case of the lizards simply stated. On the sandy beaches of Los Roques and Orchila covered with a very scanty vegetation the pitiless rays of the sun must fall on the lizards in a most uncomfortable manner, to say nothing of the heat reflected and radiated from the ground itself. From the moment the islands were separated from the mainland, a change would commence in the lizards to suit them to their altered position, a change which has resulted in their present wide divergence from the mainland type so far as colour is concerned.

WM. ACKROYD

Sowerby Bridge, July $3^{1}$

\section{Spicula in Helix}

THE spicula observed by your correspondent (NATURE, vol, xx. p. 316) lying underneath the albuminiparous gland in some specimens of Helix aspersa are probably Spicula Amoris. Their cal- careous composition if coupled with a quadrangular outline would establish the fact.

Beddington Park

\section{Distribution of Black Rat}

IT may interest Mr. Middleton to know that in $\mathrm{r} 866$, the black rat was abundant on the top of the Island of Ascension; below, the "House of Hanover" held sway. I counted about a dozen, lying in a manure pit, that had been killed in the farm stables, during the previous two or three days, and was told by a soldier, who did not think them anything out of the way, that "there were plenty of them." E. L. LAYARD Noumea, May $3^{\text {I }}$

\section{ON THE STRUCTURE OF THE STYLAS TERIDAE: A FAMILY OF HYDROID STONY CORALS}

T NTIL the late Prof. Agassiz in 1859 announced his discovery that the Milleporidæ were Hydroids and not Anthozoans, it was confidently believed that all living recent stony corals were most closely allied in their essential structure to the common sea anemones of our coasts. The majority of stony corals still remain under the old category. The beautiful calcareous branched or variously formed objects so familiar as ornaments or as exhibits in museums are nearly all of them formed within the bodies of animals which differ in no important features from the flower-like anemones of our aquariums. The sea anemones have no hard skeleton to support their soft and yielding bodies; the corals differ from them in that they have such skeletons. These are, during the life of the animals of which they form part, entirely embedded within the soft tissues, and only become exposed and appear in the familiar form when the animals are dead and their flesh has been removed from their bones by the action of decomposition or more speedy solution by means of caustic alkalis.

It seems difficult to explain how the popular error by which corals are spoken of as structures built up by coral "insects" arose. It is still perpetuated with considerable misleading detail in some schoolroom books, and it is quite common to meet still with educated persons who regard coral as analogous to honeycomb, and look upon it as built up by the "insects" in much the same sort of way.

Very many corals are solitary or simple, being the skeletons of single animals. As an example may be cited the mushroom-coral, the common chimney ornament, which is the largest known simple coral. This is the skeleton of a single animal comparable with and closely allied to a sea anemone. By far the greater number of forms of corals are, however, compound; that is to say, they are the skeletons of colonies of animals, each com parable to a single mushroom coral but living united together for mutual benefit and with their skeleton s fused together to form a common support. Such are for example the various branched Madreporas and other similar forms, and the brain-corals so often brought home from the tropics by sailors.

Until Prof. Agassiz made the discovery above alluded to it was supposed that all stony corals were, as above described, Anthozoan. He found, however, to the astonishment of naturalists, that the corals known as the Milleporidæ were the skeletons of animals allied not to the sea anemones, but to the jelly-fish or Meduse and the common Hydra of our fresh-water ponds and ditches. The Milleporidæ, of which there are very many species, which, however, fall within but a single genus, Millepora, are either branched and form shrub-like or antler-like masses of various sizes, or occur as irregular rounded lumps, often spreading in their growth over dead corals or orher objects, and encrusting them. The Millepores are distin-

s The Croonian Lecture, 2878 . 
guished by the fineness and abundance of the minute pores by which the surfaces of their skeletons are pierced. The animals belonging to these corals had not been examined until they were investigated by Agassiz, and as he was not able to make any extended investigation of their structure, his results were long accepted by many naturalists with considerable hesitation. During the voyage of H.M.S. Challenger I studied the structure of several species of Millepora in detail, with the result of confirming Prof. Agassiz's results and yielding a detailed account of the minute structure of these organisms, which is almost complete, excepting with regard to their generative organs, which remain as yet entirely unknown.

In pursuing my observations on corals, I discovered that another family of stony corals, as well as the Milleporidæ, is also Hydroid in structure. This is the family of the Stylasteridæ, an account of the structure of which was selected by the Royal Society as the Croonian lecture for last year, and has just appeared in the new volume of the Philosophical Transactions. In the present article I have brought together the principal results of interest which are stated in detail in the lecture.

One of the Stylasteridæ (Allopora) had previously been examined in the living condition by Prof. G. O. Sars, and Sars had suspected that this coral might be Hydroid like the Milleporide, but he had been unable to work out the details of the structure of the organism and to prove the matter with certainty. Several observers, the late Dr. Gray, Prof. Verrill, and the Count de Pourtales, had observed the distinciness of the Stylasteridre, and noticed that there were remarkable peculiarities characterising this family of corals.

The Hydroid stony corals, the Milleporidx and Stylasteridæ, I have placed in a specia! sub-order, the Hydrocorallinæ. Though the two families are well distinguished from one another, they show many close resemblances in structure.

Amongst the Hydrocorallinæ there do not exist, as there do amongst the Anthozoan corals, any simple or solitary species; there are no Hydroid corals comparable thus to the mushroom corals, the only forms known are compoind colonies. In the case of the Anthozoan corals it seems probable that in the progress of development a simple ancestral form derived from a sea-anemone developed a calcareous skeleton, and that from this solitary form compound corals were derived as subsequent modifications; or, rather, it is not unlikely that several solitary ancestors developed calcareous skeletons independently, and that from each of them different compound forms resulted. In the case of the Hydrocorallinæ, on the other hand, it seems probable that the calcareous skeleton was first developed as a support to already formed colonies, and that no solitary ancestor with a calcareous support preceded them.

Almost all the recent Anthozoan corals belong to the Hexactinia or corals which, like the common sea anemones, have the radially disposed soft structures of their bodies and the corresponding radial plates of their skeletons arranged in multiples of the number six. These Hexactinian Anthozoan corals are termed the Madreporaria. It is a very remarkable $f \mathrm{ct}$ that amongst all the vast number of species of compo $1 \mathrm{~d}$ Madreporaria known, there seems to exist no instance of a modification of certain of the animals composing the colonies by a subdivision of labour amongst them for the general good to the colony. Amongst Alcyonarian corals and Hydroid corals such a sub-division of labour exists, but for some reason or other such high specialisation seems never to have been attained amongst Madreporaria.

In the case of the Hydrocorallinæ, the subdivision of labour amongst the members of the colonies is carried to a most interesting perfection. It reaches considerable completeness in the Milleporidæ, but in the more advanced Stylasteridæ attains a most elaborate complexity.
In all the Hydrocorallinæ the bard skeleton is very porous, being traversed in all directions by canals which branch and join one another in all directions. Witbin these canals are lodged corresponding branching and anastomosing tubes composed of soft tissues, which form a complex meshwork within the coral mass, and convey a general circulation common to all the members of the colony. In all the Hydrocorallinæ two kinds of polyps or zooids occur. The more numerous kind are devoid of any mouth or stomach, and act simply as catchers of food for the colony. These are hence termed dactylozooids. The less numerous kind have each a mouth and stomach, and are hence termed gastrozooids; they receive the food from the dactylozooids, and swallow it, and their bases being in direct communication with'the general circulation, they nourish with the results of their digestion the dactylozooids and all the component parts of their colony.

In the Milleporidæ the dactylozooids, when expanded, are long and slender, and are provided all along their lengths with short tentacles each of which bears a knob at its end. In the case of the Stylasteridæ, however, the dactylozooids have quite lost their tentacles, and are simply long, slender, tapering bodies, reduced to the aspect of simple tentacles themselves. In the Milleporidæ the gastrozooids are provided with short tentacles round their mouths, and such tentacles are also present in the case of the gastrozooids of most of the genera of Stylasteridæ, the number present varying in the case of each genus. In some genera of Stylasteridæ, however, even the gastrozooids have lost their tentacles, and remain as simple cylindrical digestive sacs; in these instances the entire colonies are devoid of tentacles altogether.

The zooids are lodged within pits or pores on the surfaces of the corals, which are termed gastropores or dactylopores, according to the kind of zooid belonging to them. The gastropores are larger than the dactylopores in correspondence with the size of the respective zooids. In most species of Millepora and several genera of Stylasteridæ the gastropores and dactylopores, intermingled with one another, are scattered irregularly all over the surfaces of the corals; but in one species of Millepora occurring at Tahiti the pores are gathered with some considerable regularity into circular groups, each of which is composed of a single centrally-placed gastro. pore and a surrounding zone of six or seven dactylopores. In this case the zone of dactylozooids in each group or system ministers to the wants of the single gastrozooid of that system.

The complexity of relations of the zooids advances no further in the case of the Milleporidæ, but in that of the Stylasteridæ many additional complications exist. In several genera (Allopora, Stylaster, Cryptohelia, Astylus) the pores occur only in regular circular systems, which are termed cyclosystems. In each of these cyclosystems there is a deep centrally-placed gastropore and a circular zone of from five to upivards of twenty dactylopores. The mouths of the dactylopores, instead of being circular in outline, are drawn out into the forms of long slits, which are disposed in the cyclosystems in a regular radial manner towards the central gastropore. In species in which the dactylopores are numerous and closely packed in the systems, a thin wall only of hard coral skeleton is left intervening between them. Hence each system has closely the appearance of an ordinary Anthozoon coral cup, with its radiating septal plates, and so close is the resemblance that Gray and all earlier observers did not doubt that Stylaster and its allies were essentially similar in structure to the ordinary branching corals, such as Oculina.

The essential difference between a cyclosystem of a Stylasterid and an Anthozoan coral cup is, however, as wide as possible. The radiating plates in the case of the Anthozoan coral are skeletal structures developed 
within the body of a single polyp, whereas the so similar-looking radiating plates in the case of the cyclosystem are skeletal plates developed outside the bodies of the numerous component polyps altogether, and separating a number of adjacent polyps from one another. The peculiar radiate form of the cyclosystems of the Stylasterids has no doubt been gradually developed as the result of the constant bending inwards of the dactylozooids in each system to reach their gastrozooid when further and further retracted within its pore. The dactylozooids have thus in course of generations pulled the mouths of their pores out into the form of slits all directed inwards towards the gastropore in each system. In the case of some genera the gastrozooids have carried matters so far that they have ceased to be retracted within their own pores when at rest, but double themselves inwards for safety within the wide mouths of their gastropores. In one genus (Cryptohelia) a further protection is afforded to the zooids by the growth in front of each system of a delicate lid-like lamina of hard coral skeleton, which projects in front, and shields all the zooids when retracted.

In some genera of Stylasteridæ the zooids are not gathered into cyclosystems at all, but various other complications occur. Thus, in some genera there are two kinds of dactylozooids, larger and smaller. The larger and longer, in order to gain more reach in procuring food, are borne at the tips of long spine-like projections of the hard skeletons of the corals, whilst the smaller dactylozooids are lodged in small pores at the bases of these spines where they are in close proximity to the gastrozooids. The larger dactylozooids presumably catch the food, and are helped in delivering it to the gastrozooids by their shorter companions.

As before stated, the mode of generation of the Milleporidx is as yet unknown, but it is certain that it differs in one important particular from that of the Stylasteridæ. In these latter small cavities, or brood pouches, termed ampullæ, are formed in the hard skeleton of the coral, and in these the generative elements are developed. Each coral stock is of separate sex, all its components being either male or female. The walls of the ampullæ in many cases project above the surfaces of the corals, and are especially prominent in female stocks, since they have in these cases to contain large embryos. In some specimens of Stylasteridæ the ampullæ are very conspicuous to the naked eye, looking like small convex blisters closely packed on the surfaces of the coral branches. They are particularly well marked in the case of female stocks of species of Distichopora, which are thus especially serviceable for class demonstration, and when the generative function of the ampullæ is premised, afford evidence at a glance of the bydroid nature of the Stylasteridæ. The ova are developed within the ampullæ to the condition of mature planulæ, when they are set free by the gradual thinning and final rupture of the ampullar walls and swim off to start fresh colonies. It is highly probable that the masses of tissue from which the ova are developed, and which protect them during growth, are representatives of polyps, which have, like the dactylozooids, lost their mouths, and have come by restriction of function to be mere egg-bags as it were.

In all the Stylasterida, even those with very complex cyclosystems, there is a complete circulatory connection between the different systems and all parts of the colony, as well as amongst the components of each system. Thus in these complex mutual benefit associations, certain members of the colonies catch the food, but do not eat it, others receive it from them and nourish the whole colony thereby, whilst others again neither catch food nor eat it, but devote themselves entirely to the production and rearing of the young.

The ancestral forms from which the Hydrocorallinze have been developed must have been colonies closely similar in essential structure to their present descenclants, but with all their component zooids provided with mouths and generative organs, all alike catching food and digesting it, and possibly all taking their share in the production of young. In such colonies further development may be conceived of as having arisen by either of two processes. All the zooids may have become gradually modified, so that each performed only one function and thus had certain of its structures aborted to fit it for this special end. If such be the history of the development of the Hydrocorallinæ then the dactylozooids are to be looked on as they have been regarded throughout this paper as representatives of zooids which in the ancestral condition were provided with a mouth and stomach, but in which these structures as well as the generative structures have become rudimentary by disuse. Similarly in the case of the gasterozooids the functions of prehension bave to a large extent been lost, and the zooids have become, in some cases, mere stomachs.

On the other hand the view may be taken that the gastrozooids alone represent the original zooids of the ancestral colony. They remain, having lost their generative organs and to a greater or less extent their prehensile ones because additional zooids have been formed by budding in order to provide for the wants of the colony in these particulars. On this view the generative zooids and dactylozooids were originally budded out in the condition in which they now exist or in one not so complete as it is at present, nor so perfectly adapted to their present function. On this view they have lost no structure by disuse, but have rather advanced in complexity with development but only in their own specialised direction.

The former view of the antecedent history of the suborder Hydrocorallinæ has been here adopted, because the presence of several structures which occur as rudiments in connection with the dactylozoids and generative zooids, but which are fully developed in connection with the gastrozooids, seem to bear out this conclusion. As examples may be cited the calcareous styles which gave the name to the family Stylasteridæ. These styles are small projections of the hard skeletons of the corals which support the gastrozooids within their pores. In several genera rudimentary styles are found to occur in connection with the dactylozooids.

The Stylasteridæ, in the complexity of their compound stocks, form an interesting parallel to the Siphonophora. In the Siphonophora the several components of the compound organisms are by the best authorities regarded not as individual zooids, but as portions of the organisms which, being budded out, tend in their growtb to assume more and more the form of individuals. The question is to some extent one of nomenclature, but it must not be forgotten that though the diverse elements composing the organism in the case of the Siphonophora may seem closely paralleled by those of which that of a Stylasterid is made up, the past history of the two organisms may be very different. In the one case an ancestral already compound organism may have gradually modified its similar zooids to subserve division of labour, whilst in the other a simple ancestor may have gradually developed a similar compound organism by throwing out buds of various forms, which have come more or less to approach itself in complexity.

H. N. MOSELEY

\section{IRIDO-PLATINUM}

THE volume of the proces-verbaux of the International Commission of Weights and Measures published in Paris last year ${ }^{1}$ contains, among other matter of much value, an interesting appendix by MM. Sainte-Claire Deville and Stas, who were requested by the Commission to ascertain the composition of the platinum-iridium alloy employed in the preparation of the rules and cylinders $\approx$ Gauthier-Villars. Paris, 2878 . 